Folia Cardiologica 2017 tom 12 , nr 1 , strony $50-54$ DOI: $10.5603 /$ FC.2017.0005 Copyright @ 2017 Via Medica ISSN 2353-7752

\title{
Waskulopatia w przeszczepionym sercu - nowe trendy w diagnostyce i leczeniu
}

\section{Cardiac allograft vasculopathy - new trends in diagnostics and treatment}

\author{
Maria Milczarek ${ }^{1}$, Małgorzata Wojciechowska ${ }^{1}$, Artur Mamcarz $^{2}$, \\ Agnieszka Cudnoch-Jędrzejewska ${ }^{1}$ \\ ${ }^{1}$ Zakład Fizjologii Doświadczalnej i Klinicznej, Laboratorium Centrum Badań Przedklinicznych \\ Warszawskiego Uniwersytetu Medycznego \\ ${ }^{2}$ III Klinika Chorób Wewnętrznych i Kardiologii Warszawskiego Uniwersytetu Medycznego
}

\section{Streszczenie}

Waskulopatia naczyń wieńcowych (CAV) jest jednym z najpoważniejszych powikłań u pacjentów po transplantacji serca. Znajduje się ona wśród trzech najczęstszych przyczyn zgonów w tej grupie chorych w czasie powyżej 3 lat od przeszczepienia. Jest to przyspieszona forma miażdżycy o złożonej patogenezie, w której znaczącą rolę odgrywają zarówno mechanizmy immunologiczne, jak i zakażenia wirusowe. Klasyczne czynniki ryzyka rozwoju miażdżycy mają wpływ na postęp waskulopatii w późniejszym okresie po transplantacji. Ze względu na niespecyficzne objawy ważną rolę w rozpoznawaniu CAV odgrywa diagnostyka obrazowa. Oprócz angiografii, będącej „złotym standardem” diagnostycznym, na znaczeniu zyskują nowoczesne metody obrazowania. Wewnątrznaczyniowa ultrasonografia oraz jej połączenie z wirtualną histologią, a także optyczna tomografia koherencyjna pozwalają na dokładny pomiar wskaźnika MIT, który jest czynnikiem prognostycznym rozwoju CAV. Ponadto metody te umożliwiają ocenę budowy blaszek i odróżnianie zmian waskulopatycznych od klasycznej miażdżycy. Wciąż poszukuje się najkorzystniejszych połączeń leków immunosupresyjnych oraz antyproliferacyjnych, które stanowią podstawę w zapobieganiu i hamowaniu postępu waskulopatii. Zaobserwowano, że skuteczność tych samych farmaceutyków różni się w zależności od zastosowanego schematu leczenia. Oprócz leczenia farmakologicznego niektórzy pacjenci odnoszą korzyści z zabiegów angioplastyki lub pomostowania aortalno-wieńcowego. Główne kierunki badań w zakresie CAV dotyczą metod wczesnego wykrywania zmian i skutecznego hamowania rozwoju tej groźnej patologii.

Słowa kluczowe: CAV, miażdżyca, przeszczepienie serca, waskulopatia

Folia Cardiologica 2017; 12, 1: 50-54

\section{Wstęp}

Rozwój transplantologii w zakresie przeszczepiania serca istotnie wpłynął na poprawę rokowania u pacjentów ze schyłkową niewydolnością serca. Metoda ta nie tylko wydłuża życie, ale także poprawia jego jakość. Wśród chorych aż $90 \%$ badanych w ciągu 1-3 lat po przeszczepieniu osiąga 80-100\% w skali Karnofskyego [1]. Jednak mimo tak pozytywnych wyników współczesna medycyna zmaga się z wieloma powikłaniami u pacjentów po transplantacji serca (HTx, heart transplantation). Jednym z nich jest waskulopatia przeszczepionego serca (CAV, cardiac allograft

Adres do korespondencji: dr n. med. Małgorzata Wojciechowska, Zakład Fizjologii Doświadczalnej i Klinicznej, Laboratorium Centrum Badań Przedklinicznych, Warszawski Uniwersytet Medyczny, ul. Banacha 1b, 02-097 Warszawa, e-mail: gosiawojciech@yahoo.com 
Tabela 1. Różnice między waskulopatią przeszczepionego serca (CAV, cardiac allograft vasculopathy) a miażdżycą (na podstawie [11])

\begin{tabular}{|c|c|c|}
\hline Cecha & CAV & Miażdżyca \\
\hline \multirow[t]{2}{*}{ Zajęcie naczyń } & Tętnice nasierdziowe i śródścienne & Główne tętnie nasierdziowe \\
\hline & $\begin{array}{l}\text { Objęte odcinki proksymalne i dystalne tętnic } \\
\text { oraz ich gałęzie }\end{array}$ & Głównie dotyczy proksymalnych odcinków tętnic wieńcowych \\
\hline Obraz uszkodzenia & $\begin{array}{l}\text { Rozlane, koncentryczne pogrubienie błony } \\
\text { wewnętrznej }\end{array}$ & $\begin{array}{l}\text { Ogniskowa, ekscentryczna proliferacja, degeneracyjne } \\
\text { uszkodzenie błony wewnętrznej w odcinkach proksymalnych }\end{array}$ \\
\hline Inicjacja zmian & $\begin{array}{l}\text { Proliferacja komórek mięśni gładkich w błonie } \\
\text { wewnętrznej, akumulacja lipidów }\end{array}$ & Gromadzenie pasm lipidowych \\
\hline Progresja & Gwałtowna & Powolna (dekady) \\
\hline Powikłania & Pękanie blaszki rzadko spotykane & Często pęknięcie blaszki \\
\hline
\end{tabular}

vasculopathy), która jest przyspieszoną postacią choroby naczyń wieńcowych i występuje u 8\% chorych w pierwszym roku, u 30\% po 5 latach i u $50 \% 10$ lat po transplantacji $[1,2]$. Waskulopatia przeszczepionego serca należy do trzech najczęstszych przyczyn zgonu (obok chorób nowotworowych i niewydolności nerek) w czasie powyżej 3 lat od przeszczepienia [1]. Nadal poszukuje się nowych metod diagnostycznych i leczniczych w tej patologii.

\section{Patogeneza}

Powstawanie waskulopatii po transplantacji jest złożonym procesem. Główną rolę odgrywają czynniki immunologiczne, wśród których wyróżnia się infiltrację błony wewnętrznej naczyń (tunica intima) przez populację komórek zapalnych, w tym limfocytów i makrofagów [3]. Podkreśla się również znaczenie swoistych przeciwciał produkowanych przez aktywowane limfocyty B. Nie bez znaczenia pozostaje uszkodzenie śródbłonka podczas zabiegu przeszczepiania. W badaniu na modelu świńskim wykazano, że w naczyniach, które podczas transplantacji serca pozbawiono śródbłonka, miesiąc po operacji dochodziło do nasilonego procesu hiperplazji błony wewnętrznej, a także zwężenia tych naczyń [4]. Zaobserwowano wcześniejsze pojawienie się CAV u pacjentów, u których wystąpiły co najmniej 2 epizody ostrego odrzucania komórkowego (ACR, acute cellular rejection) [5].

Warto wspomnieć o udziale zakażeń w patogenezie CAV. Jednym z wirusów o udowodnionym związku z rozwojem waskulopatii jest cytomegalowirus (CMV, cytomegalovirus). Zarówno objawowe, jak i bezobjawowe zakażenia skracają okres rozwoju CAV, a także czas życia pacjentów [6]. Zbadano także związek między zakażeniami wirusem zapalenia wątroby typu B (HBV, hepatitis B virus), zarówno u dawców, jak i u biorców [7], wirusem zapalenia wątroby typu C (HCV, hepatitis $C$ virus) u dawców [8] a podwyższonym ryzykiem waskulopatii.

Uważa się, że klasyczne czynniki ryzyka miażdżycy odgrywają istotną rolę w rozwoju choroby w późniejszym czasie. Dochodzi wtedy do nakładania się typowej miażdżycy na zmiany waskulopatyczne. Za istotne uznaje się między innymi wiek dawcy powyżej 50. roku życia [5], palenie tytoniu [9], cukrzycę typu 2, rozpoznaną po Htx oraz dyslipidemię [10]. W tabeli 1 przedstawiono różnice w charakterystyce histologicznej CAV i miażdżycy [11].

\section{Diagnostyka}

U pacjentów po przeszczepieniu z powodu odnerwienia serca nie obserwuje się typowych dolegliwości stenokardialnych, a ich pojawienie się sugeruje zaawansowanie procesu chorobowego [12]. Pierwszymi objawami częściej występującymi niż w przypadku klasycznej miażdżycy tętnic wieńcowych są objawy niewydolności serca, zaburzenia rytmu lub nagły zgon sercowy [13]. Dlatego tak ważne jest poszukiwanie metod wczesnego wykrywania i leczenia zmian o charakterze waskulopatii. Według obowiązujących wytycznych The International Society for Heart and Lung Transplantation (ISHLT) z 2010 roku klasyczna angiografia stanowi nadal „złoty standard” w diagnostyce CAV [14]. Stopnie zaawansowania CAV w obrazie angiograficznym opisano w tabeli 2. Jej wykonanie zaleca się przesiewowo raz do roku lub co 2 lata. U pacjentów, u których nie stwierdzono nieprawidłowości w ciągu 3-5 lat, można prowadzić rzadsze kontrole [15]. Obecnie ze względu na brak przekonujących dowodów klinicznych nie zaleca się rutynowego wykonywania ultrasonografii wewnątrznaczyniowej (IVUS, intravascular ultrasound). Metoda ta jednak staje się coraz bardziej popularna. Pozwala na zaobserwowanie dwufazowości CAV, polegającej na początkowym pogrubieniu błony wewnętrznej, z zachowaniem światła naczynia oraz zmianach o charakterze zwężenia, do których dochodzi w późniejszym rozwoju choroby [16]. Wykonanie IVUS 4-6 tygodni oraz rok po Htx pozwala wykryć chorobe wieńcową przekazaną od dawcy, wczesne zmiany w naczyniach, a także może dostarczyć informacji prognostycznych [12]. W badaniu wieloośrodkowym z zastosowaniem IVUS wykazano, że 
Tabela 2. Stopnie zaawansowania waskulopatii przeszczepionego serca (CAV, cardiac allograft vasculopathy) na podstawie angiografii według The International Society for Heart and Lung Transplantation (ISHLT) (źródło [15])

\begin{tabular}{|c|c|}
\hline Stopień CAV & Charakterystyka \\
\hline ISHLT CAV (bez znaczenia) & Bez zmian angiograficznych \\
\hline ISHLT CAV ${ }_{1}$ (łagodna) & $\begin{array}{l}\text { LCA < 50\% lub naczynie I rzędu < 70\% lub zwężenie jakiejkolwiek gałęzi < 70\% (włączając rozlane } \\
\text { zwężenie), bez dysfunkcji graftu }\end{array}$ \\
\hline ISHLT CAV ${ }_{2}$ (umiarkowana) & $\begin{array}{l}\text { LCA }<50 \% \text {, pojedyncze naczynie I rzędu } \geq 70 \% \text { lub izolowane zwężenie gałęzi } \geq 70 \% \text { w gałęziach } \\
2 \text { systemów, bez dysfunkcji graftu }\end{array}$ \\
\hline ISHLT CAV ${ }_{3}$ (ciężka) & $\begin{array}{l}\text { LCA } \geq 50 \% \text { lub zwężenie } \geq 70 \% \text { w } \geq 2 \text { naczyniach I rzędu lub izolowane zwężenie gałęzi } \geq 70 \% \\
\text { w } 3 \text { systemach lub ISHLT } C A V_{1} / C_{C} V_{2} \text { z dysfunkcją graftu (LVEF } \leq 45 \% \text { zazwyczaj z obecnością } \\
\text { miejscowych zaburzeń ruchomości ściany) lub udowodnione cechy restrykcyjnej niewydolności } \\
\text { przeszczepionego serca }\end{array}$ \\
\hline
\end{tabular}

LCA (left coronary artery) - lewa tętnica wieńcowa; LVEF (left ventricular ejection fraction) - frakcja wyrzutowa lewej komory

ultrasonograficzny przyrost wskaźnika maksymalnej grubości błony wewnętrznej (MIT, maximal intimal thickness) o co najmniej $0,5 \mathrm{~mm}$ w pierwszym roku po HTx niekorzystnie wpływa na 5-letnie przeżycie pacjentów oraz wiąże się z przyspieszonym rozwojem CAV [17]. Połączenie badania IVUS z wirtualną histologią (VH, virtual histology) umożliwia uzyskanie dodatkowych informacji o budowie blaszek. Dwudziestoletnia obserwacja pacjentów za pomocą IVUS-VH wykazała postępujące zastępowanie elementów włóknistych i włóknisto-tłuszczowych przez tkankę martwiczą ze zwapnieniami [18].

Coraz częściej wśród metod diagnostyki CAV wymienia się optyczną tomografię koherencyjną (OCT, optical coherence tomography). Unikatową cechą tego badania jest zdolność do prześwietlania zwapnień oraz obrazowania błony wewnętrznej i mierzenia jej grubości [19]. W badaniu pośmiertnym wskaźnika IMT (intima-media thickness), w którym porównywano zgodność OCT oraz IVUS z wynikiem histopatologicznym, wykazano większą czułość pierwszej metody [20]. W jednej z ostatnich prac opisano dwuwarstwową budowę zmian miażdżycowych w naczyniach wieńcowych, co łłumaczono nałożeniem się nowo powstałej waskulopatii na zmiany miażdżycowe obecne w sercu dawcy [21]. W pracy Cassar i wsp. [22] z 2013 roku z wykorzystaniem OCT zwrócono uwage na pojawienie się typowych zmian miażdżycowych, takich jak wapnienie, zakrzepy oraz niestabilność blaszek, minimum 4 lata po przeszczepieniu. Wykazano także dodatni związek między osoczowym stężeniem wysoce czułej troponiny $\mathrm{T}$ (hsTnT, high-sensitive troponin $T$ ) a stopniem zaawansowania CAV (MIT $\geq 0,5 \mathrm{~mm}$ ) [23]. Być może ten rodzaj testu laboratoryjnego, używanego dotychczas we wczesnej diagnostyce ostrego zespołu wieńcowego, znajdzie także zastosowanie w monitorowaniu postępu CAV.

\section{Leczenie}

Zapobieganie i leczenie waskulopatii po przeszczepieniu serca to ogromne wyzwanie współczesnej transplantolo- gii. Coraz więcej badań dotyczy wpływu poszczególnych leków immunosupresyjnych na rozwój CAV. Według wytycznych ISHLT podstawą terapii immunosupresyjnej są inhibitory kalcyneuryny (CNI, calcineurin inhibitors): cyklosporyna, takrolimus. Podkreśla się także rolę leków antyproliferacyjnych (MMF, mykofenolan mofetilu) oraz inhibiotrów kinazy mTOR (mammalian target of ramapycin) - ewerolimusu (EVE) i sirolimusu (SRL), w opóźnianiu powstania i progresji waskulopatii [15]. W badaniach z ostatnich lat porównywano skuteczność tych wymienionych substancji. W randomizowanym, wieloośrodkowym badaniu z 2013 roku obserwowano rozwój CAV już w pierwszym roku po HTx. U części pacjentów stosowano EVE ze zredukowaną dawką CNI, u pozostałych - MMF ze standardową dawką CNI. W grupie leczonej EVE uzyskano istotnie mniejszy przyrost MIT, oceniany za pomocą IVUS, oraz rzadsze występowanie CAV (definiowane jako $\Delta \mathrm{MIT}$ $\geq 0,5 \mathrm{~mm}$ ). $Z$ kolei pacjenci przyjmujący MMF charakteryzowali się lepszym profilem lipidowym [24]. W innym badaniu przedstawiono zbliżone wnioski dotyczące korzyści z zastosowania EVE w porównaniu z MMF w pierwszym roku stosowania. Nie potwierdzono jednak długotrwałej skuteczności tej terapii w zapobieganiu rozwojowi CAV [25]. Obserwację tę tłumaczy się różnymi mechanizmami odpowiadającymi za wczesną i późną postać CAV. Jak już wspomniano, w początkowym okresie po HTx główną rolę odgrywają odpowiedź immunologiczna i proliferacja komórek mięśni gładkich, podczas gdy w obserwacji długoterminowej większe znaczenie ma wpływ klasycznych czynników ryzyka miażdżycy [26]. Dodatkowych informacji dostarczyło wieloośrodkowe badanie, w którym zastosowano IVUS-VH do oceny morfologii i zaawansowania zmian w grupach pacjentów leczonych EVE lub MMF. W okresie powyżej 5 lat od transplantacji serca stwierdzono nasilone wapnienie oraz martwice, poza tym zwiększone gromadzenie cząsteczek adhezyjnych oraz czynnika von Willebranda u chorych przyjmujących EVE [27]. Obecnie nie jest znany wpływ tych procesów na powikłania odległe i rokowanie CAV. 
Sprzecznych informacji dostarczyło jedno z najnowszych doniesień, w którym porównywano czas rozwoju CAV u pacjentów leczonych MMF lub po konwersji na EVE. Do badania włączono chorych, u których minął co najmniej rok od HTx. Pacjentów stosujących EVE podzielono na dwie podgrupy ( $<2$ lat po HTx; $\geq 2$ lata po HTx). Wykazano zwolnienie rozwoju CAV w obu podgrupach w porównaniu z pacjentami leczonymi MMF. Autorzy sugerują, że korzystne efekty mogły stanowić wynik połączenia EVE z takrolimusem. Większość pacjentów we wcześniej opisanych badaniach przyjmowała EVE z cyklosporyną [28].

Oprócz farmakoterapii, w CAV powszechnie stosuje się przezskórne interwencje wieńcowe $(\mathrm{PCl}$, percutaneus coronary interventions). Ze względu na rozsiany charakter zmian w CAV w porównaniu z ogniskowymi zmianami miażdżycowymi rewaskularyzajca jest zabiegiem paliatywnym. Udowodniono przewagę stentów uwalniających lek (DES, drug-eluting stent) nad stentami metalowymi (BMS, bare metal stent) pod względem mniejszej liczby restenoz [29, 30]. Mimo że pomostowanie aortalno-wieńcowe (CABG, coronary artery bypass grafting) nie jest metodą leczenia pierwszego rzutu u chorych z CAV, również z powodu rozległości zmian, istnieją dane wskazujące korzyści z jego zastosowania w wybranych grupach pacjentów. W jednym z badań przeżycie po 7 latach od zastosowania CABG wyniosło 83\% [31]. Obecnie jedyną radykalną metodą leczenia waskulopatii pozostaje retransplantacja.

\section{Podsumowanie}

Od czasu wydania ostatnich wytycznych ISHLT w 2010 roku dotyczących diagnostyki i leczenia CAV [15] ukazało się wiele prac, które częściowo uzupełniły wiedzę na temat tego poważnego powikłania po przeszczepieniu serca. Dzięki nowoczesnej diagnostyce udało się dokładniej zbadać morfologię zmian CAV oraz ich ewolucję. Brakuje jednak danych na temat wpływu nowo odkrytych mechanizmów na długotrwałe przeżycie pacjentów. Ponieważ CAV jest jednym z najistotniejszych czynników skracających przeżycie chorych po przeszczepieniu, niezwykle ważne jest dalsze poszukiwanie metod wczesnej diagnostyki i skutecznego leczenia tej patologii. Niewielka liczba pacjentów po HTx wpływa na trudności w prowadzeniu wiarygodnych badań klinicznych w tej grupie chorych.

\section{Konflikt interesów}

Autorzy nie zgłaszają konfliktu interesów.

\section{Abstract}

Cardiac allograft vasculopathy (CAV) is one of the most significant complications in heart transplant patients. It is mentioned among three most frequent causes of death in patients over 3 years after heart transplant. It is an accelerated form of atherosclerosis with complex pathogenesis, including immunological reactions and viral infections. Classical atherosclerosis risk factors tend to influence the progress of CAV in the later stage. Due to nonspecific symptoms, diagnostic imaging is of a great value in recognizing CAV. Apart from angiography, which is the "gold standard" in diagnostics, modern imaging is increasingly gaining in importance. Intravascular ultrasound and its connection with virtual histology, as well as optical coherence tomography enable an accurate measurement of maximal intimal thickness (MIT), which is a prognostic factor of CAV progression. Moreover, these methods make it possible to assess the structure of plaques and to distinguish between CAV and atherosclerotic plaques. There are still researches conducted to find out the most favorable connections of immunosuppresive and antiproliferative drugs, which are the basis of CAV prevention and treatment. It has been observed that the effect of treatment differs depending on the used scheme. Apart from pharmacological treatment, angioplasty or coronary artery bypass graft can be profitable in some patients. The main goals of CAV researches are early diagnostics possibilities and effective suppression of this dangerous pathology progression. Key words: CAV, atherosclerosis, heart transplant, vasculopathy

Folia Cardiologica 2017; 12, 1: 50-54

\section{Piśmiennictwo}

1. Yusen RD, Christie JD, Edwards LB, et al. International Society for Heart and Lung Transplantation. The Registry of the International Society for Heart and Lung Transplantation: Thirtieth Adult Lung and Heart-Lung Transplant Report - 2013; focus theme: age. J Heart Lung Transplant. 2013; 32(10): 965-978, doi: 10.1016/j.healun.2013.08.007, indexed in Pubmed: 24054805.

2. Hollis IB, Reed BN, Moranville MP. Medication management of cardiac allograft vasculopathy after heart transplantation. Pharmaco- therapy. 2015; 35(5): 489-501, doi: 10.1002/phar.1580, indexed in Pubmed: 26011142.

3. Zimmer RJ, Lee MS. Transplant coronary artery disease. JACC Cardiovasc Interv. 2010; 3(4): 367-377, doi: 10.1016/j.jcin.2010.02.007, indexed in Pubmed: 20398862.

4. El-Hamamsy I, Stevens LM, Vanhoutte PM, et al. Injury of the coronary endothelium at implantation increases endothelial dysfunction and intimal hyperplasia after heart transplantation. J Heart Lung Transplant. 
2005; 24(3): 251-258, doi: 10.1016/j.healun.2003.12.012, indexed in Pubmed: 15737750.

5. Sato T, Seguchi O, Ishibashi-Ueda H, et al. Risk stratification for cardiac allograft vasculopathy in heart transplant recipients - annual intravascular ultrasound evaluation. Circ. J. 2016; 80(2): 395-403, doi: 10.1253/circj.cj-15-1037.

6. Johansson I, Andersson R, Friman V, et al. Cytomegalovirus infection and disease reduce 10-year cardiac allograft vasculopathy-free survival in heart transplant recipients. BMC Infect Dis. 2015; 15: 582, doi: 10.1186/s12879-015-1321-1, indexed in Pubmed: 26703239.

7. Haji SA, Avery RK, Yamani MH, et al. Donor or recipient hepatitis B seropositivity is associated with allograft vasculopathy. J Heart Lung Transplant. 2006; 25(3): 294-297, doi: 10.1016/j.healun.2005.10.007, indexed in Pubmed: 16507422.

8. Haji SA, Starling RC, Avery RK, et al. Donor hepatitis-C seropositivity is an independent risk factor for the development of accelerated coronary vasculopathy and predicts outcome after cardiac transplantation. J Heart Lung Transplant. 2004; 23(3): 277-283, doi: 10.1016/ /S1053-2498(03)00148-7, indexed in Pubmed: 15019636.

9. Rickenbacher PR, Pinto FJ, Lewis NP, et al. Correlation of donor characteristics with transplant coronary artery disease as assessed by intracoronary ultrasound and coronary angiography. Am J Cardiol. 1995; 76(5): 340-345, indexed in Pubmed: 7639157.

10. Chamorro $\mathrm{Cl}$, Almenar L, Martínez-Dolz L, et al. Do cardiovascular risk factors influence cardiac allograft vasculopathy? Transplant Proc. 2006; 38(8): 2572-2574, doi: 10.1016/j.transproceed.2006.08.034, indexed in Pubmed: 17098006.

11. Rahmani M, Cruz RP, Granville DJ, et al. Allograft vasculopathy versus atherosclerosis. Circ Res. 2006; 99(8): 801-815, doi: 10.1161/01. RES.0000246086.93555.f3, indexed in Pubmed: 17038650.

12. Skorić B, Čikeš M, Ljubas Maček J, et al. Cardiac allograft vasculopathy: diagnosis, therapy, and prognosis. Croat Med J. 2014; 55(6): 562-576, indexed in Pubmed: 25559827.

13. Chang HY, Yin WH, Lo LW, et al. The utilization of twelve-lead electrocardiography for predicting sudden cardiac death after heart transplantation. Int J Cardiol. 2013; 168(3): 2665-2672, doi: 10.1016/j. ijcard.2013.03.029, indexed in Pubmed: 23571163.

14. Mehra MR, Crespo-Leiro MG, Dipchand A, et al. International Society for Heart and Lung Transplantation working formulation of a standardized nomenclature for cardiac allograft vasculopathy-2010. J Heart Lung Transplant. 2010; 29(7): 717-727, doi: 10.1016/j. healun.2010.05.017, indexed in Pubmed: 20620917.

15. Costanzo MR, Dipchand A, Starling R, et al. International Society of Heart and Lung Transplantation Guidelines. The International Society of Heart and Lung Transplantation Guidelines for the care of heart transplant recipients. J Heart Lung Transplant. 2010; 29(8): 914-956, doi: 10.1016/j.healun.2010.05.034, indexed in Pubmed: 20643330.

16. Tsutsui H, Ziada KM, Schoenhagen P, et al. Lumen loss in transplant coronary artery disease is a biphasic process involving early intimal thickening and late constrictive remodeling: results from a 5-year serial intravascular ultrasound study. Circulation. 2001; 104(6): 653-657, indexed in Pubmed: 11489770.

17. Kobashigawa JA, Tobis JM, Starling RC. Multicenter intravascular ultrasound validation study among heart transplant recipients: outcomes after five years. J Am Coll Cardiol. 2005; 45(9): 1532-1537, doi: 10.1016/j.jacc.2005.02.035, indexed in Pubmed: 15862430 .

18. Hernandez JM, de Prada JA, Burgos V, et al. Virtual histology intravascular ultrasound assessment of cardiac allograft vasculopathy from 1 to 20 years after heart transplantation. J Heart Lung Transplant.
2009; 28(2): 156-162, doi: 10.1016/j.healun.2008.11.915, indexed in Pubmed: 19201341.

19. Pinto TL, Waksman R. Clinical applications of optical coherence tomography. J Interv Cardiol. 2006; 19(6): 566-573, doi: 10.1111/j.15408183.2006.00201.x, indexed in Pubmed: 17107374.

20. Kume T, Akasaka T, Kawamoto T, et al. Assessment of coronary intima-media thickness by optical coherence tomography: comparison with intravascular ultrasound. Circ J. 2005; 69(8): 903-907, indexed in Pubmed: 16041157.

21. Imamura T, Kinugawa K, Murasawa T, et al. Cardiac Allograft Vasculopathy Can Be Distinguished From Donor-Transmitted Coronary Atherosclerosis by Optical Coherence Tomography Imaging in a Heart Transplantation Recipient. Int Heart J. 2014; 55(2): 178-180, doi: 10.1536/ihj.13-279.

22. Cassar A, Matsuo Y, Herrmann J, et al. Coronary atherosclerosis with vulnerable plaque and complicated lesions in transplant recipients: new insight into cardiac allograft vasculopathy by optical coherence tomography. Eur Heart J. 2013; 34(33): 2610-2617, doi: 10.1093/ /eurheartj/eht236, indexed in Pubmed: 23801824.

23. Garrido IP, García-Lara J, Pinar E, et al. Optical coherence tomography and highly sensitivity troponin $\mathrm{T}$ for evaluating cardiac allograft vasculopathy. Am J Cardiol. 2012; 110(5): 655-661, doi: 10.1016/j. amjcard.2012.04.047, indexed in Pubmed: 22640973.

24. Kobashigawa JA, Pauly DF, Starling RC, et al. Cardiac allograft vasculopathy by intravascular ultrasound in heart transplant patients: substudy from the Everolimus versus mycophenolate mofetil randomized, multicenter trial. JACC Heart Fail. 2013 Oct;1(5):389-99. 2013; 1(5): 389-399, doi: 10.1016/j.jchf.2013.07.002, indexed in Pubmed: 24621971.

25. Chou NK, Jan CF, Chi NH, et al. Cardiac allograft vasculopathy compared by intravascular ultrasound sonography: everolimus to mycophenolate mofetil--one single-center experience. Transplant Proc. 2012; 44(4): 897-899, doi: 10.1016/j.transproceed.2012.03.041, indexed in Pubmed: 22564578.

26. Masetti M, Potena L, Nardozza M, et al. Differential effect of everolimus on progression of early and late cardiac allograft vasculopathy in current clinical practice. Am J Transplant. 2013; 13(5): 1217-1226, doi: 10.1111/ajt.12208, indexed in Pubmed: 23621161.

27. Arora S, Erikstad I, Ueland T, et al. Virtual histology assessment of cardiac allograft vasculopathy following introduction of everolimus - results of a multicenter trial. Am J Transplant. 2012; 12(10): 2700-2709, doi: 10.1111/j.1600-6143.2012.04234.x, indexed in Pubmed: 22958738.

28. Watanabe T, Seguchi O, Nishimura K, et al. Suppressive effects of conversion from mycophenolate mofetil to everolimus for the development of cardiac allograft vasculopathy in maintenance of heart transplant recipients. Int J Cardiol. 2016; 203: 307-314, doi: 10.1016/j. ijcard.2015.10.082, indexed in Pubmed: 26523360.

29. Tremmel JA, Ng MKC, Ikeno F, et al. Comparison of drug-eluting versus bare metal stents in cardiac allograft vasculopathy. Am J Cardiol. 2011; 108(5): 665-668, doi: 10.1016/j.amjcard.2011.04.014, indexed in Pubmed: 21684511.

30. Lee MS, Kobashigawa J, Tobis J. Comparison of percutaneous coronary intervention with bare-metal and drug-eluting stents for cardiac allograft vasculopathy. JACC Cardiovasc Interv. 2008; 1(6): 710-715, doi: 10.1016/j.jcin.2008.10.001, indexed in Pubmed: 19463388.

31. Bhama JK, Nguyen DQ, Scolieri S, et al. Surgical revascularization for cardiac allograft vasculopathy: Is it still an option? J Thorac Cardiovasc Surg. 2009; 137(6): 1488-1492, doi: 10.1016/j.jtcvs.2009.02.026, indexed in Pubmed: 19464469. 